\title{
Can non-destructive DNA extraction of bulk invertebrate samples be used for metabarcoding?
}

\author{
Melissa E Carew ${ }^{\text {Corresp., }}{ }^{1}$, Rhys A Coleman ${ }^{2}$, Ary A Hoffmann ${ }^{1}$ \\ ${ }^{1}$ School of BioSciences, The University of Melbourne, Melbourne, Victoria, Australia \\ 2 Applied Research, Melbourne Water, Melbourne, Victoria, Australia \\ Corresponding Author: Melissa E Carew \\ Email address: mecarew@unimelb.edu.au
}

Background. High throughput DNA sequencing of bulk invertebrate samples or metabarcoding is becoming increasingly used to provide profiles of biological communities for environmental monitoring. As metabarcoding becomes more widely applied, new reference DNA barcodes linked to individual specimens identified by taxonomists are needed. This can be achieved through using DNA extraction methods that are not only suitable for metabarcoding but also for building reference DNA barcode libraries.

Methods. In this study, we test the suitability of a rapid non-destructive DNA extraction method for metabarcoding of freshwater invertebrate samples.

Results. This method resulted in detection of taxa from many taxonomic groups, comparable to results obtained with two other tissue-based extraction methods. Most taxa could also be successfully used for subsequent individual-based DNA barcoding and taxonomic identification. The method was successfully applied to field-collected invertebrate samples stored for taxonomic studies in $70 \%$ ethanol at room temperature, a commonly used storage method for freshwater samples.

Discussion. With further refinement and testing, non-destructive extraction has the potential to rapidly characterise species biodiversity in invertebrate samples, while preserving specimens for taxonomic investigation. 
1 Can non-destructive DNA extraction of bulk invertebrate samples be used for

2 metabarcoding?

3 Melissa E. Carew*, Rhys A. Coleman† and Ary A. Hoffmann*

4

5 *School of BioSciences, Bio21 Institute, 30 Flemington Rd, The University of Melbourne 3010,

6 Victoria, Australia.

$7 \dagger$ Applied Research, Melbourne Water, PO Box 4342, Melbourne 3001

8 Victoria, Australia.

9

10 Author for correspondence: Melissa Carew

11 Address: Bio21 institute, 30 Flemington Rd, The University of Melbourne, Victoria, Australia,

123010.

13 Phone: +61390353530

14 E-mail: mecarew@unimelb.edu.au

15 


\section{Abstract}

17

Background. High throughput DNA sequencing of bulk invertebrate samples or metabarcoding is becoming increasingly used to provide profiles of biological communities for environmental monitoring. As metabarcoding becomes more widely applied, new reference DNA barcodes

21 linked to individual specimens identified by taxonomists are needed. This can be achieved

22 through using DNA extraction methods that are not only suitable for metabarcoding but also for 23 building reference DNA barcode libraries.

24 Methods. In this study, we test the suitability of a rapid non-destructive DNA extraction method 25 for metabarcoding of freshwater invertebrate samples.

26 Results. This method resulted in detection of taxa from many taxonomic groups, comparable to

27 results obtained with two other tissue-based extraction methods. Most taxa could also be 28 successfully used for subsequent individual-based DNA barcoding and taxonomic identification.

29 The method was successfully applied to field-collected invertebrate samples stored for 30 taxonomic studies in $70 \%$ ethanol at room temperature, a commonly used storage method for 31 freshwater samples.

32 Discussion. With further refinement and testing, non-destructive extraction has the potential to 33 rapidly characterize species biodiversity in invertebrate samples, while preserving specimens for 34 taxonomic investigation. 


\section{Introduction}

Species identification using high throughput DNA sequencing (HTS) of bulk samples containing multiple species (metabarcoding) is being increasingly applied in environmental monitoring, as it enables rapid identification of a wide range of taxa (Yu et al. 2012; Zhou et al. 2013; Gibson et al. 2014; Gibson et al. 2015; Elbrecht et al. 2017). However, associating sequences generated by metabarcoding with species names is dependent on comprehensive DNA barcoding libraries where individual specimens identified by taxonomists are DNA barcoded (Hajibabaei et al. 2011; Baird \& Hajibabaei 2012; Carew et al. 2013; Zimmermann et al. 2014). Some taxonomic groups and geographic regions have comprehensive DNA barcode libraries (e.g. Hebert et al. 2013; Hendrich et al. 2015; Hebert et al. 2016), but many taxonomic groups or taxa from other geographical regions lack such coverage (see Carew et al. 2017; Kranzfelder, Ekrem \& Stur 2017). This means that when environmental samples containing invertebrates are processed using metabarcoding, many sequences cannot be identified to species. This does not prevent the use of DNA barcodes for environmental monitoring, as sequences can be grouped into molecular operational taxonomic units (MOTUs) (Blaxter et al. 2005), which can be associated with various environmental parameters (i.e. Pawlowski et al. 2014; Lanzén et al. 2016). However, it does mean that pre-existing taxonomic and environmental information based on other approaches cannot be easily integrated (Carew et al. 2007; Schafer et al. 2011). Furthermore, an MOTU approach prevents the accuracy of DNA barcodes for species identifications to be tested (Lee 2004; Moritz \& Cicero 2004), and it complicates the detection of PCR artifacts and chimeras when analyzing metabarcoding data (Creer et al. 2010; Carlsen et al. 2012).

To ensure that reference DNA barcode libraries are developed for invertebrate samples that are processed with HTS, field samples can be taken in duplicate, where one is used for 
59 creating local reference DNA barcodes based on individual specimens and the other is

60 homogenized and used for metabarcoding (e.g. Gibson et al. 2015). This approach can lead to a

61 high species detection rate with HTS (Gibson et al. 2014; Gibson et al. 2015). However, it is

62 possible that some taxa, particularly rare species, will not be found in both samples. If these

63 species are only detected in the metabarcoded sample, there is not an opportunity to produce a

64 reference DNA barcode when specimens are destroyed during DNA extraction.

65 Where only single samples are available, dissecting tissue or legs from individuals used

66 for HTS keeps specimens largely intact for individual reference DNA barcoding. Detailed

67 photographs of individual specimens can further assist identification, especially where damage

68 occurs during dissection (e.g. Sweeney et al. 2011). However, this is a slow and difficult process,

69 particularly for small taxa such as water mites, or for taxa with tissues inside shells, such as

70 bivalves and gastropods. The preservation ethanol can also be used for non-destructive

71 metabarcoding, leaving specimens undamaged (e.g. Hajibabaei et al. 2012). However, this

72 approach can be less successful than tissue-based extraction for metabarcoding, depending on

73 ethanol quality or re-use, storage time, presence of PCR inhibitors, as well as species biomass

74 and composition (Hajibabaei et al. 2012; Carew et al. 2013).

75 A non-destructive DNA extraction method that enables reliable detection of taxa in bulk

76 samples would help to overcome some of these challenges. Non-destructive methods involving

77 temporarily immersing whole specimens in an extraction buffer have been successfully applied

78 to individual specimens for reference DNA barcoding (Rowley et al. 2007; Castalanelli et al.

79 2010; Porco et al. 2010; Krosch \& Cranston 2012;Wong et al. 2014; Cornils 2015). However,

80 they have not been tested with bulk invertebrate samples, like those used for metabarcoding. It is

81 not clear whether DNA from the same individuals extracted non-destructively for metabarcoding 
82 can then be used for creating reference DNA barcodes. Also, it is not known whether combining

83 species from different taxonomic groups with varying body forms in a non-destructive DNA

84 extraction can be successfully metabarcoded to determine species biodiversity.

85 In this study, we aim to test whether it is possible to apply non-destructive DNA

86 extractions to bulk invertebrate sample intended for metabarcoding. We first examine if

87 individual invertebrates from common freshwater orders can be successfully extracted for

88 metabarcoding and then reference DNA barcoding. We subjected taxa to a non-destructive total

89 genomic extraction using a commercial kit, and followed with a Chelex extraction to test

90 whether the same specimens can provide adequate DNA after multiple extractions. We then

91 inspected the morphological integrity of specimens for taxonomic work after non-destructive

92 extraction. Next, we constructed multiple bulk invertebrate samples for metabarcoding to

93 compare species detection rates of samples processed using non-destructive DNA extractions to

94 two different tissue- based DNA extraction methods. Finally, we tested the non-destructive DNA

95 extraction method on samples collected for routine bioassessment, but stored in different ethanol

96 concentration and temperatures, to determine if non-destructive extraction could be applied to

97 routinely stored invertebrate collections.

\section{Material \& Methods}

100

101

Component 1: Non-destructive DNA extractions on individuals.

102

103

The first component of this study aimed to determine whether a non-destructive DNA extraction

can be used to obtain DNA from whole individuals from common freshwater macroinvertebrate orders/subclasses (Fig 1A). To test this, we included a small experiment (Experiment 1a) that examined the incubation time required for specimens to be immersed in extraction buffer to 
107 obtain DNA without destruction of morphological characters, followed by a second broader

108 experiment (Experiment 1b) to see how the method performed on individuals from multiple

109 families covering 15 common orders/ classes/ subclasses.

110 A total genomic extraction (Extraction 1; Fig 1A), which is commonly used to prepare

111 samples for HTS (e.g. Elbrecht, Peinert \& Leese 2017), was used to obtain DNA from whole and

112 intact invertebrate specimens. For extraction, ethanol was removed using a pipette from

113 microcentrifuge tubes containing individual specimens, then $180 \mu \mathrm{L}$ T1 buffer and $25 \mu \mathrm{L}$ of

114 proteinase K (extraction buffer) from the Nucleospin DNA extraction kit (Macherey-Nagel Inc.

115 Bethlehem, PA, USA) were added. We tested the whether the presence of ethanol interfered with

116 the DNA extraction by soaking several specimens overnight in TE buffer prior to extraction, but

117 found no difference in successful amplification between soaked specimens and those with

118 ethanol removed just prior to extraction (Table S1). Specimens were then incubated in the

119 extraction buffer at $56^{\circ} \mathrm{C}$. Based on other studies (Rowley et al. 2007; Castalanelli et al. 2010;

120 Porco et al. 2010), we incubated specimens for $1 \mathrm{hr}$ in the extraction buffer, but also tested a

121 subset of taxa for 30 mins and/or $3 \mathrm{hrs}$ depending on their levels of sclerotization (Table S1 and

122 S2). The extraction buffer was removed and placed into a new $1.5 \mathrm{ml}$ microcentrifuge tube for

123 DNA extraction using a Nucleospin DNA extraction kit (Macherey-Nagel Inc. Bethlehem, PA,

124 USA) following the manufacturer's instructions. After extraction buffer removal, absolute

125 ethanol was added to microcentrifuge tubes containing whole specimens to preserve them for

126 subsequent Chelex extraction and taxonomic identification. The condition of specimens was

127 inspected under a dissecting microscope (Leica Microsystem and Instruments, Wetzlar,

128 Germany). 
A Chelex extraction (Extraction 2; Fig 1A) was then performed to establish if two

130 extractions of the same specimen was possible, i.e. an initial extraction intended for

131 metabarcoding followed by an extraction intended for individual DNA barcoding. The material

132 used for Chelex extraction varied among taxonomic groups, depending on how specimens

133 needed to be prepared for identification (Table S2) but followed the methods of Carew et al.

134 (2003)

135

The success of both DNA extractions was determined by amplification of the DNA

136

137

138

139

140

141

142

143

144

145

146 147 processed).

148

149

150

151 barcode region (Hebert et al. 2003) using the primer set HCOI2198/LCOI1490 from (Folmer et al. 1994) according to Carew et al. (2015), as this primer set was known to amplify the majority of taxa considered in the study. Some DNA barcode amplicons isolated with DNA extraction methods were sequenced to ensure that the intended species were extracted. Sequencing reactions were performed in both directions using an ABI 3730XL capillary sequencer (Applied Biosystems, Foster City, California, USA) with sequencing reactions and runs performed by Macrogen (Seoul, Korea)

After DNA extraction, taxa were identified to the lowest possible level using relevant taxonomic keys (see Hawking 2000). In most instances this was species, but for some groups we had difficultly identifying species due to a lack of keys, expertise or because specimens were immature or damaged (e.g. most Ephemeroptera were missing legs/cerci prior to being

All macroinvertebrate specimens used for these experiments were collected using a 250 $\mu \mathrm{m}$ net from riffle and pool habitats from several streams/rivers around the greater Melbourne area (Victoria, Australia) and stored in $100 \%$ ethanol at $-20^{\circ} \mathrm{C}$ until required. 


\section{Component 2: Bulk DNA extraction for metabarcoding}

153

154 In the second component of this study, we examined bulk DNA extraction using the nondestructive (ND) extraction protocol above (as used on individuals) and compared it to two 156 commonly used tissue-based extraction methods based on total homogenization $(\mathrm{H})$ and dissection of tissues (D) (Fig 1B). To allow a comparison between the three extraction methods (ND, H and D), we constructed three sets of invertebrate samples each containing three 'replicates'. We choose to use high numbers of individuals and a species composition representative of what we have previously found in field samples (e.g. Carew et al. 2018) to construct invertebrate samples. The first set contained 80 individuals (Sample A), the second set 100 individuals (Sample B) and third set contained 120 individuals (Sample C) (Fig 1B). One 'replicate' from each set was used to compare metabarcoding success of the ND, H and D based extraction methods. Technical replicates (i.e. metabarcoding the same DNA extraction twice) were performed on the third set containing 120 individuals to examine the robustness of species detection. Unfortunately, it was not possible to make identical replicates given that we could not mount or destroy samples to check species identification. Instead, the composition of each replicate was standardized as much as possible by selecting taxonomic groups that could be identified to a low taxonomic level under a dissecting microscope, and/or specimens that had

170 been collected from the same sites. We also used similar sized individuals for each taxon to 171 control for differences in biomass. Not all taxonomic groups considered individually in

172 component 1 could be used in constructing samples due to limited availability of material, but we 173 tried to represent animals of varying levels of sclerotization and size.

174 When constructing samples, we focused on testing how a non-destructive method could 175 be applied to small taxa only $\left(<7 \mathrm{~mm}^{2}\right)$ in bulk DNA extractions; all large taxa $\left(>7 \mathrm{~mm}^{2}\right)$ were 
176 dissected when comparing extraction methods to reduce the likelihood that larger species

177 affected the detection of overall species diversity (Elbrecht, Peinert \& Leese 2017). Furthermore,

178 larger taxa tend to be less common and/or more easily dissected than smaller taxa in bulk

179 samples, making this a practical approach.

180 When comparing the three extraction methods, smaller taxa were processed differently.

181 For completely homogenized samples $(\mathrm{H})$, dissected tissue of large taxa and complete specimens

182 of smaller taxa were combined for DNA extraction. For dissected samples (D), all taxa (both

183 large and small) were dissected and then legs/tissues were combined and homogenized for DNA

184 extraction. Dissected taxa were returned to absolute ethanol. For the non-destructive (ND)

185 approach, absolute ethanol was removed from tubes containing small taxa using a pipette and

$186180 \mu \mathrm{L}$ of buffer T1 with $25 \mu \mathrm{L}$ proteinase $\mathrm{K}$ from the Nucleospin DNA extraction kit

187 (Macherey-Nagel Inc.) was added, ensuring specimens were completely immersed. Tubes were

188 incubated for $1 \mathrm{hr}$ at $56^{\circ} \mathrm{C}$. After incubation, specimens were placed back into absolute ethanol.

189 The tissues/legs dissected from the larger taxa were homogenized separately. All

190 homogenization steps were performed in $1.5 \mathrm{ml}$ microcentrifuge tubes. Tissues were snap frozen

191 in liquid nitrogen and crushed with a sterile pestle. Then $180 \mu \mathrm{L}$ of the T1 buffer and $25 \mu \mathrm{L}$

192 proteinase $\mathrm{K}$ were added, and samples incubated for $3 \mathrm{hrs}$ at $56^{\circ} \mathrm{C}$. After incubation all samples

193 were DNA extracted using a Nucleospin tissue kit (Macherey-Nagel Inc.) following the

194 manufacturer's instructions. DNA was eluted in $100 \mu \mathrm{L}$ of the elution buffer from the

195 Nucleospin tissue kit. The time taken to prepare material for each DNA extraction method and

196 the number tubes used in extractions was recorded. Where multiple extraction tubes were used

197 for a sample, DNA extractions were combined prior to HTS. 
A subset of the individuals, representing different taxonomic groups used in bulk non199 destructive extraction, was then subjected to individual DNA extraction (see Table S3), DNA

200 barcode amplification and sequencing according to the methods described for extraction 2 201 (above).

202 203

204 205 206 207 208 209

217 For metabarcoding, we followed the non-destructive DNA extraction workflow for bulk DNA 218 219 220

221

\section{Component 3: Non-destructive DNA extraction of field-collected samples}

In the final component, we examined whether the non-destructive DNA extraction method can be used on samples collected for morphological identification as part of rapid bioassessment surveys (Fig 1C). We obtained six macroinvertebrate samples collected on two occasions (spring 2014 and autumn 2016) from three sites along the Merri Creek, Melbourne, Australia (Table S4). Prior to metabarcoding, the six samples were identified mostly to family level according to the Rapid Bioassessment Protocols developed by EPA Victoria (available at:

\section{http://www.epa.vic.gov.au/ /media/Publications/604\%201.pdf). Therefore, family level} information was available for comparison with our species level DNA barcode identifications. Sites were selected based on the diversity of macroinvertebrate families: Coburg Lake (MCL) had low macroinvertebrate diversity, Rushwood Dr (MRD) had high diversity, while the third site at O’Herns $\mathrm{Rd}(\mathrm{MOH})$ had an intermediate level. Prior to metabarcoding, spring 2014 samples were stored at room temperature in $70 \%$ ethanol, while the autumn 2016 samples were stored in $100 \%$ ethanol at $4^{\circ} \mathrm{C}$.

extraction outlined in component 2. Specimens in samples representing taxa not found with metabarcoding or had not been previously DNA barcoded were removed from samples and individually DNA barcoded. 
222

223

224

225

226

227

228

229

230

231

232

233

234

235

236

237

238

239

240

241

242

243

244

245

High throughput DNA sequencing of bulk invertebrate samples

A two-step PCR process was used to obtain amplicons for Illumina MiSeq sequencing.

The first PCR involved amplifying the DNA barcode region (Hebert et al. 2003) using three PCR primer sets. The primer sets include LCOI1490 (Folmer et al. 1994)/MLepR2 (Hebert et al. 2013); B (Hajibabaei et al. 2012)/COIBrev (5'-GATCARACAAAYARWGGYATWCGRTC-3') and miCOIintF (Leray et al. 2013) /HCOI2198 (Folmer et al. 1994). Primers were selected based on their ability to amplify a broad range of taxa. While some taxa may be missed in metabarcoding depending on the primers selected, using the same primer pairs across all extraction methods allowed a comparison of the extraction methods relative success for detecting species.

First round PCR reactions contained $2 \mu \mathrm{L}$ of DNA template, $16.4 \mu \mathrm{L}$ molecular biology grade water, $2.5 \mu \mathrm{L}$ PCR buffer (Invitrogen, Carlsbad, CA, USA), $1 \mu \mathrm{L} \mathrm{MgCl}_{2}(50 \mathrm{mM}), 2 \mu \mathrm{L}$ dNTPs mix (25 mM of each dNTP), $0.5 \mu \mathrm{L}$ forward primer $(10 \mu \mathrm{M}), 0.5 \mu 1$ reverse primer $(10$ $\mu \mathrm{M}$ ), and $0.1 \mu \mathrm{L}$ Platinum Taq polymerase (5 U/ml) (Invitrogen, Carlsbad, CA, USA) in a total volume of $25 \mu \mathrm{L}$, and were amplified in triplicate using the PCR conditions from Hajibabaei et al (2012). The PCR replicates were pooled and cleaned using a Mag-Sera magnetic beads (GE Healthcare Australia, Sydney, Australia). Cleaned amplicons were quantified with a Qubit Fluorometer using the dsDNA HS Assay Kit (Life Technologies, Carlsbad, CA, USA). Template-specific primers had Illumina adaptors incorporated onto the 5' end for the attachment of Nextera-XT Illumina indexes (Illumina Corporation, San Diego, CA, USA) in the second round of PCR. The second round PCRs were performed after pooling three amplicons in approximately equal molar ratios. Reactions used $15 \mu \mathrm{L}$ of the first-round amplicons, $25 \mu \mathrm{L}$ BIO-X-ACT short mix (Bioline, London, England), $5 \mu \mathrm{L}$ forward Nextera-XT index primer (10 
$246 \mu \mathrm{M})$, and $5 \mu \mathrm{L}$ reverse Nextera-XT primer $(10 \mu \mathrm{M})$. PCR conditions were as follows: $94^{\circ} \mathrm{C}$ for 5

247 mins followed by 12 cycles of $94^{\circ} \mathrm{C}$ for $30 \mathrm{sec}, 55^{\circ} \mathrm{C}$ for $30 \mathrm{sec}, 72^{\circ} \mathrm{C}$ for $30 \mathrm{sec}$, then 1 cycle of

$24872^{\circ} \mathrm{C}$ for 5 mins. All amplicons were then cleaned again with Mag-Sera magnetic beads (as

249 above).

250 Library quantification, normalization, pooling and the Illumina MiSeq run using a 600-

251 cycle flow cell MiSeq sequencing kit V3 (300bp x 2) (Illumina, San Diego, CA) were performed

252 by Australian Genome Research Facility Ltd (AGRF) according to the manufacturer's protocols.

253 Raw sequence data generated with HTS was deposited in the National Center for Biotechnology

254 Information (NCBI) Short Read Archive (SRA) database under BioProject PRJNA413851.

255

256

257

258 Sequences from HTS were imported into Geneious version R10 (Kearse et al. 2012) and were

259 trimmed to <197 bp. FLASH version 1.2.9 (Magoc \& Salzberg 2011) was used to merge set

260 paired reads with default settings. Merged reads were annotated with each set of forward and

261 reverse primer pairs and then extracted to isolate each of the three amplicons. Only amplicons of

262 appropriate size (+/- 6 bp of the amplicons expected size) with both forward and reverse primers

263 on each end were retained. Primers were then trimmed and a custom de novo assembly at $98 \%$

264 similarity was used to reduce redundancy in the dataset. The number of reads that contributed to

265 each contig (group of sequences with $>98 \%$ sequence similarity) from the de novo assembly was

266 recorded. Singletons and contigs containing ten or fewer reads were discarded (see Bokulich et

267 al. 2013). The remaining contigs were aligned, edited and checked for an open reading frame.

268 Contigs were then BLAST searched against a DNA barcoding reference database of freshwater

269 macroinvertebrates, and species with $>97.5 \%$ match were identified. The reference database of 
270 freshwater macroinvertebrates was constructed by downloading and combining DNA barcodes

271 from GenBank (http://www.ncbi.nlm.nih.gov/genbank/) and BOLD systems v3

272 (http://www.boldsystems.org/) databases from families or orders known to have aquatic life

273 stages. The ten best matches were also checked to ensure that species matches were specific.

274 Chimeric sequences were identified and removed with USEARCH version 9 (Edgar et al. 2011)

275 using the freshwater macroinvertebrates as a reference database. Specimens from any families

276 not detected at $>97.5 \%$ with HTS were subjected to individual DNA barcoding (see above).

277

\section{Results}

279

280

Component 1: Individual non-destructive DNA extraction

281

282

We obtained DNA suitable for amplifying DNA barcodes from individual freshwater

283

macroinvertebrates following a non-destructive DNA extraction (Table 1 and 2). Sanger

284

sequencing on amplified DNA barcodes revealed the expected species DNA. We obtained DNA

285

barcodes for all specimens in experiment 1a (Table 2), but some Acarina and Oligochaeta in

286

experiment $1 \mathrm{~b}$ that amplified did not produce amplicons that could be clearly sequenced (Table

$2873)$.

For most taxa, whole specimens only required immersion, and subsequent incubation for

one hour at $56^{\circ} \mathrm{C}$ in the $\mathrm{T} 1$ buffer with proteinase $\mathrm{K}$ from the Nucleospin kit was sufficient to extract DNA for PCR amplification. However, we found that complete digestion of tissue in species from the Gastropoda, Oligochaeta and Hirudinea (Table 2 and 3) was an issue. The 30

$292 \mathrm{~min}$ and/or $1 \mathrm{hr}$ incubation completely digested Oligochaeta and Hirudinea specimens,

293 suggesting that these orders are unlikely to be suitable for non-destructive extraction when whole 294 animals are immersed in extraction buffer for 30 mins or longer. The longer incubation of 3 hrs 
295 completely digested tissues in the Gastropoda, but some tissues remained after $1 \mathrm{hr}$ (or $30 \mathrm{~min}$ ), 296 making a second extraction possible. The presence of a shell meant that taxonomic examination 297 was also possible. We failed to obtain DNA for amplification from an adult Coleopteran after 30 $298 \mathrm{~min}$ immersed in the extraction buffer but did after an incubation time of $\geq 1 \mathrm{hr}$ (Table 2) 299 suggesting these specimens require longer immersion in extraction buffer for DNA extraction. 300 Using an one hour incubation as a standard, it was possible to obtain DNA with a non301 destructive total genomic extraction (Extraction 1) from a taxonomically wide range of species

302 (Table 3). However, we found some specimens from the Acarina, Bivalvia as well as a

303 Ceratopogonidae specimen did not amplify. Given that other specimens from these groups did

304 amplify, it is possible that the undetected taxa were extracted successfully but were not amplified 305 by the standard Folmer DNA barcoding primers (LCOI1490/HCOI2198).

306 We were also able to perform a second Chelex extraction (Extraction 2) on most 307 specimens, including those where DNA was extracted from legs (Amphipoda, Trichoptera, 308 Ephemeroptera, Plecoptera, Hemiptera, Coleoptera (larvae), Megaloptera and Decapoda). 309 However, only some Diptera and Acarina were successfully amplified in the second Chelex extraction. Dissected Diptera tissues tended to stick to forceps during dissection, and this may

311 have resulted in some material being lost. For the Acarina, all tissue with DNA may have been completely digested in the first extraction because of the small size of specimens. Most specimens were sufficiently intact for morphological identification (Fig S1A).

314 Some specimens had a coating of white residue from the T1 extraction buffer, but this could be 315 removed by adding more ethanol or by manual removal using forceps. Many of the less

316 sclerotized specimens had a hyaline appearance, but this assisted identification when specimens 317 were mounted, particularly for Diptera (i.e. Chironomidae). However, the Amphipoda were 
318 substantially damaged during the extraction process and were often missing antennae and legs

319 which are needed for taxonomic identification.

320

321

Component 2: Bulk DNA extraction for metabarcoding

322

323 The three extraction methods based on homogenization, dissection and non-destructive

324 extraction of small taxa varied in the amount of time and number of tubes required (Table 1 and

325 4). The most rapid method involved completely homogenizing small taxa in samples (H) along

326 with dissected large taxa, but this method also used the most microcentrifuge tubes for DNA

327 extraction, increasing the cost of extraction per sample. The slowest method was sample

328 dissection (D) of all taxa, which took 2-3 times longer than the homogenization $(\mathrm{H})$ protocol, but

329 this method meant all DNA could be extracted in a single microcentrifuge tube. Non-destructive

330 extraction (ND) only took 1.5 times longer than the homogenization (H) protocol to complete,

331 but used fewer microcentrifuge tubes.

All DNA extraction methods produced amplicons for each of the three HTS primer sets, with greater than $84 \%$ of the expected taxa detected in samples of known taxon composition

334 (Table 5). The DNA extraction based on dissection of specimens (D) produced the most reliable

335 detection of taxa, with only a single taxon, Micronecta sp., not detected in the sample containing 33680 individuals (Fig 2). Samples that were homogenized or subjected to non-destructive DNA

337 extraction were more variably detected. Generally, homogenized samples with $\geq 100$ individuals

338 detected most taxa (Fig 2). However, six species, Cosmioperla sp. ABX7338 (Eustheniidae),

339 Anisocentropus latifascia (Calamoceratidae), Paratanytarsus grimmii (Chironomidae),

340 Micronecta sp. (Corixidae) Tasmanophlebia sp. ACM3395 (Oniscigastridae) and Diplacodes

341 haematodes (Libellulidae), were not detected in the sample containing 80 individuals. Similarly, 
342 up to four taxa were not detected in the samples that underwent non-destructive extraction. These

343 often represented the more sclerotized taxa. For example, heavily sclerotized Coleopterans from

344 the Dytiscidae, Ptilodactylidae and Elmidae were not detected in some samples (Fig 2). We also

345 found that some chironomids were not detected in the sample containing 100 individuals; and the

346 Calocidae (Trichoptera), which can retract into a stone case, were not detected in samples

347 containing 80 and 100 individuals.

348 Particular extraction methods performed better for some taxa in terms of the number of

349 reads (or sequences) produced and consistency of detection (Fig 2). For example, adult

350 Dytiscidae (Necterosoma sp.) consistently produced $>1800$ reads when whole adult beetles were

351 homogenized for DNA extraction, but when legs were dissected or whole specimens were

352 immersed for DNA extraction, $<20$ reads were produced. In contrast, the ND method

353 consistently detected Corixidae (Micronecta $\mathrm{sp}$.) with $>70$ reads, whereas H and D consistently

354 produced a low number of reads, and sometimes failed to detect this taxon. Most of the

355 remaining taxa were readily detected with all three extraction methods. Technical replication of

356 sample $\mathrm{C}$ with all three extraction methods showed that metabarcoding method was robust (Fig

357 2). There were only two instances of where taxon represented with low reads was detected in one 358 replicate but not the other.

359 Overall, when multiple specimens were combined for non-destructive DNA extraction in 360 the T1 buffer with proteinase $\mathrm{K}$ and incubated for $1 \mathrm{hr}$, there was less digestion of tissues in 361 specimens when compared to digestion in the individual DNA extraction trials (Fig S2). In

362 particular, amphipod specimens were largely unaltered by bulk non-destructive extraction. After 363 non-destructive DNA extraction, several taxa were successfully amplified and DNA sequenced 364 following a second Chelex extraction (Table S3). 
366

367

368

369

370

371

372

373

374

375

376

377

378

379

380

381

382

383 characters.

Component 3: Detection of macroinvertebrate taxa in field samples.

A high number of sequences were obtained for each of the field-collected samples from Merri Creek, with the exception of the 2014 Coburg Lake (MCL 2014) sample (Fig 3). Overall, most taxa were detected in samples, including the 2014 Coburg Lake sample (Table 5). Species from the orders Gastropoda, Diptera, Coleoptera, Ephemeroptera, Hemiptera and Trichoptera were detected through the ND protocol (Table 1; Fig 3). However, we found that gastropods from the family Hydrobiidae (which have an operculum) were consistently missed with this protocol. We also encountered some individual taxa that were not detected in samples. These tended to be small specimens, such as the Hydroptilidae in the 2016 Coburg Lake sample (MCL) and the Tanypodinae in the 2016 O'Herns Rd (MOH 2016) sample, or more sclerotized specimens such as the Corixidae in the 2014 MCL sample and the Dytiscidae in the $2014 \mathrm{MOH}$ sample. Some non-detections likely resulted from amplification failure rather than extraction failure; e.g. some non-insect taxa, involving species of Oligochaeta, Dugesiidae and Hirudinea, were not detected. There were no obvious differences in the likelihood of detection of species in the 2014 samples compared to 2016 samples (Fig 3), even though the latter were better preserved for DNA isolation after being stored in $100 \%$ ethanol at $4^{\circ} \mathrm{C}$ after collection rather than in $70 \%$ ethanol at room temperature.

Specimens subjected to the non-destructive extraction protocol remained suitable for subsequent DNA barcoding and taxonomic examination, as established through DNA amplification and sequencing of the DNA barcode region and the presence of taxonomic 


\section{Discussion}

390

391 Our study showed that non-destructive DNA extraction could be used for preparing invertebrate

392 samples for metabarcoding. It can allow many different taxa from samples used for

393 metabarcoding to also be used for individual DNA barcoding and taxonomic examination,

394 particularly at the larval/nymph stage. This can help reference DNA barcoding for species level

395 identification, an important step given that incomplete DNA barcoding reference libraries remain

396 a key limitation to identifying species when conducting metabarcoding of environmental samples

397 (Aylagas, Borja \& Rodriguez-Ezpeleta 2014; Cristescu 2014; Carew et al. 2017; Elbrecht et al.

398 2017). In addition, using a non-destructive extraction method can facilitate 'more targeted'

399 production of DNA barcoding reference libraries, particularly where samples have first been

400 identified to coarser taxonomic levels (i.e. family/genus), such as those from rapid bioassessment

401 surveys (i.e. Carew et al. 2016; Elbrecht et al. 2017) as it enables specimens to be examined after

402 they are metabarcoded. In this case, metabarcoding can be conducted first and specimens without

403 DNA barcodes can be recognized later based on morphological examination. These taxa can be

404 removed from samples and be targeted for individual DNA barcoding and further taxonomic

405 investigation to build DNA barcode library coverage. This process is particularly useful for areas

406 where routine surveys are conducted or for sites which are repeatedly surveyed, leading to

407 locally comprehensive DNA reference libraries for determining species diversity. With further

408 testing, non-destructive extraction may become particularly useful when invertebrate samples

409 cannot be destroyed for metabarcoding, such as those in archived or museum collections (i.e.

410 Carew et al. 2016).

411 While more reliable detection of biodiversity (see Elbrecht et al. 2017) may be possible

412 with DNA extraction protocols using complete homogenization and replication of the extraction 
413 step, we did not to compare the effect of replication at the extraction step in this study.

414 Therefore, it was unclear whether replication would improve the detection of taxa using non-

415 destructive extraction. However, we did complete technical replication of one sample for each

416 extraction method when metabarcoding. This revealed that our metabarcoding was highly

417 reproducible, with same taxa detected in each replicate when using non-destructive extraction.

418 While the other two extraction methods failed to detect one taxon represented by a low number

419 of reads between replicates. This showed that for this sample replication of the metabarcoding

420 step was not important for increasing detection of biodiversity. However, replication of more

421 samples would be useful to determine if this is always the case.

422 Overall, species detection success for the extraction methods trialled in this study were

423 similar to those employed by other metabarcoding studies using invertebrate samples (Gibson et

424 al. 2014; Elbrecht \& Leese 2015; Carew et al. 2016; Elbrecht, Peinert \& Leese 2017; Elbrecht et

425 al. 2017). We found the number of species detected with metabarcoding in samples prepared

426 using non-destructive DNA extraction were similar to those where small taxa were dissected or

427 whole individuals homogenized. Moreover, large taxa which were processed via homogenization

428 in all extraction methods were mostly detected at a similar rate to those prepared using non-

429 destructive DNA extraction.

430 However, where we did not detect taxa, there was bias towards particular groups for the

431 three extraction methods tested here. For example, heavily sclerotized taxa such as Coleoptera

432 were readily detected when whole individuals were homogenized, but often failed to be detected

433 when subjected to non-destructive DNA extraction. It is likely more DNA is released by

434 homogenization of the whole animal, resulting in more DNA being available for PCR. Typically,

435 species biomass is linked to detection success when metabarcoding, and large or more common 
436 species can affect the detection of smaller rarer species that contribute less DNA (Elbrecht \&

437 Leese 2015; Downie et al. 2016; Elbrecht, Peinert \& Leese 2017). PCR biases, due to PCR

438 primer selection and the number of primer sets used, can also lead to metabarcoding failing to

439 detect some taxa from particular orders or families (Clarke et al. 2014; Brandon-Mong et al.

440 2015; Aylagas et al. 2016; Elbrecht \& Leese 2017). Our lower detection rates in field samples

441 probably occurred because of a lack of degeneracy in metabarcoding DNA primers, especially in

442 the case of non-insect taxa, such as the Oligochaeta, Hirudinea and Dugesiidae. Additional

443 primer sets, such as those suggested in Elbrecht et al. (2017) which are specifically designed for

444 freshwater invertebrates, could improve the detection of these taxa.

445

While non-destructive DNA extraction did create some amplification bias when

446 metabarcoding, the method could be modified to improve detection of certain taxa. For example,

447 more sclerotized taxa (adult and some larval Coleoptera), or taxa retracted into a stone case

448 (some Trichoptera e.g. Calocidae) or having shell with an operculum (Gastropoda e.g.

449 Hydrobiidae), were less likely to be detected. To counter this, a longer incubation time in the T1

450 extraction buffer with proteinase K may be needed during bulk non-destructive extraction to

451 release sufficient DNA for metabarcoding. Therefore, it may be necessary to separate these taxa

452 from less sclerotized specimens and then use an incubation time $>1 \mathrm{hr}$ for non-destructive DNA

453 extraction. Based on initial trials, up to $3 \mathrm{hr}$ may be suitable for these animals, as DNA barcodes

454 were successfully amplified when an individual non-destructive DNA extraction was performed.

455 While this would increase the time taken to conduct DNA extractions due to the requirement for

456 coarse sorting, it would likely be more rapid than dissecting specimens to preserve taxonomic

457 features. Further testing and replication considering a broader range of taxa would be useful to 
458 refine the non-destructive DNA extraction protocol for routine use, especially where validation

459 of metabarcoding and individual DNA barcoding for reference libraries are still required.

460 There was a substantial difference in appearance of specimens extracted non-

461 destructively as individuals compared to those extracted in bulk. For example, most Diptera and

462 Amphipoda were morphologically unaltered after bulk extraction but had a strong hyaline

463 appearance after individual-based extraction. The hyaline appearance likely reflected a high

464 degree of tissue digestion after $1 \mathrm{hr}$ of incubation in the extraction buffer. In contrast, in most

465 other sclerotized taxa, bulk versus individual extraction had little impact on detection and the

466 former approach often left specimens in better condition for individual DNA barcoding and

467 taxonomic examination. While dissection of all taxa in samples also allowed for taxa to be re-

468 examined, this took substantial time and often led to some taxa being damaged. In particular,

469 small Diptera and Gastropoda were not easily dissected, often resulting in damaged taxonomic

470 characters needed for identification. The morphological integrity of the smaller taxa was better

471 preserved using non-destructive DNA extraction.

472 Non-destructive DNA extraction of small taxa in combination with dissection of large

473 taxa, and those unsuited to non-destructive DNA extraction (e.g. Oligochaeta, Hirudinea and

474 Dugesiidae), enabled DNA barcoding of taxa with varying levels of sclerotization from over 15

475 different macroinvertebrate orders. This included invertebrate samples that were stored for at

476 least three years in $70 \%$ ethanol at room temperature which is a common practice when

477 morphological examination is needed (Rosenberg \& Resh 1993; Haase et al. 2004), and samples

478 stored in $100 \%$ ethanol at $4^{\circ} \mathrm{C}$ which provides better preservation of DNA (Baird et al. 2011;

479 Stein et al. 2014). This means the non-destructive approach could be trialed for extracting DNA

480 from archived or museum collections, even if invertebrates have been stored in $70 \%$ ethanol for 
481 up to 3 years. However, taxon detection becomes problematic in samples stored for greater than

482 five year in sub-optimal conditions for DNA preservation (i.e. Carew et al. 2016). Therefore,

483 further testing of non-destructive DNA extraction would be useful to determine how it performs

484 on older material.

485

486

487

488

489

490

491

492

493

494

495

496

497

498

499

500 and Cameron Amos for providing macroinvertebrate samples for this study.

\section{Conclusions} variety of freshwater invertebrate species for bulk DNA extraction and subsequent of large taxa, detection of species diversity is comparable to other DNA extraction methods. of invertebrate samples for metabarcoding, while enabling the same samples to be used for samples not specifically stored for DNA -based approaches.

\section{Acknowledgements}

The authors would like to thank Claudette Kellar, David Sharley, Steve Marshall, Eddie Tsyrlin

501

In summary, we show that non-destructive DNA extraction protocols can be used for preparing a metabarcoding. When non-destructive DNA extraction of small taxa is combined with dissection

With further refinement the approach offers means to increase the speed of bulk DNA extraction individual DNA barcoding and taxonomic identification. The approach also appears suitable for 


\section{References}

503

504 Aylagas E, Borja Á, Irigoien X, Rodríguez-Ezpeleta N. 2016. Benchmarking DNA

505

506

507

508

509

510

511

512

513

514

515

516

517

518

519

520

521

522

523 metabarcoding for biodiversity-based monitoring and assessment. Frontiers in Marine Science 3. DOI:10.3389/fmars.2016.00096.

Aylagas E, Borja A, Rodriguez-Ezpeleta N. 2014. Environmental status assessment using DNA metabarcoding: Towards a genetics based Marine Biotic Index (gAMBI). PLoS ONE 9:e90529. DOI:10.1371/journal.pone.0090529.

Baird DJ, Hajibabaei M. 2012. Biomonitoring 2.0: A new paradigm in ecosystem assessment made possible by next-generation DNA sequencing. Molecular Ecology 21:2039-2044. DOI:10.1111/j.1365-294X.2012.05519.x.

Baird DJ, Pascoe TJ, Zhou X, Hajibabaei M. 2011. Building freshwater macroinvertebrate DNAbarcode libraries from reference collection material: Formalin preservation vs specimen age. Journal of the North American Benthological Society 30:125-130. DOI:10.1899/10013.1 .

Blaxter M, Mann J, Chapman T, Thomas F, Whitton C, Floyd R, Abebe E. 2005. Defining operational taxonomic units using DNA barcode data. Philosophical Transactions of the Royal Society of London Series B, Biological Sciences 360:1935-1943. DOI:10.1098/rstb.2005.1725.

Bokulich NA, Subramanian S, Faith JJ, Gevers D, Gordon JI, Knight R, Mills DA, Caporaso JG. 2013. Quality-filtering vastly improves diversity estimates from Illumina amplicon sequencing. Nature Methods 10:57-59. DOI:10.1038/nmeth.2276. 
524 Brandon-Mong GJ, Gan HM, Sing KW, Lee PS, Lim PE, Wilson JJ. 2015. DNA metabarcoding

525 of insects and allies: an evaluation of primers and pipelines. Bulletin of Entomological $526 \quad$ Research 105:717-727. DOI:10.1017/S0007485315000681.

527 Carew ME, Nichols SJ, Batovska J, St Clair R, Murphy NP, Blacket MJ, Shackleton ME. 2017. 528 A DNA barcode database of Australia's freshwater macroinvertebrate fauna. Marine and

529 Freshwater Research 68: 1788-1802. DOI:10.1071/MF16304.

530 Carew ME, Hoffmann AA. 2015. Delineating closely related species with DNA barcodes for

531

532

533

534

535

536

537

538

539

540

541

542

543

544 routine biological monitoring. Freshwater Biology 60:1545-1560. DOI:10.1111/fwb.12587.

Carew ME, Kellar CR, Pettigrove VJ, Hoffmann AA. 2018. Can high-throughput sequencing detect macroinvertebrate diversity for routine monitoring of an urban river? Ecological Indicators 85:440-450. DOI:https://doi.org/10.1016/j.ecolind.2017.11.002.

Carew ME, Metzeling L, St Clair R, Hoffmann AA. 2016. Detecting invertebrate species in archived collections using next-generation sequencing. Molecular Ecology Resources 7: 915-930. DOI:10.1111/1755-0998.12644.

Carew ME, Pettigrove V, Cox RL, Hoffmann AA. 2007. The response of Chironomidae to sediment pollution and other environmental characteristics in urban wetlands. Freshwater Biology 52:2444-2462. DOI:10.1111/j.1365-2427.2007.01840.x.

Carew ME, Pettigrove V, Hoffmann AA. 2003. Identifying chironomids (Diptera: Chironomidae) for biological monitoring with PCR-RFLP. Bulletin of Entomological Research 93:483-490. DOI:10.1079/BER2003268. 
545 Carew ME, Pettigrove VJ, Metzeling L, Hoffmann AA. 2013. Environmental monitoring using 546 next generation sequencing: Rapid identification of macroinvertebrate bioindicator 547 species. Frontiers in Zoology 10:45. DOI:10.1186/1742-9994-10-45.

548 Carlsen T, Aas AB, Lindner D, Vrålstad T, Schumacher T, Kauserud H. 2012. Don't make a 549 550 mista(g)ke: is tag switching an overlooked source of error in amplicon pyrosequencing studies? Fungal Ecology 5:747-749. DOI:10.1016/j.funeco.2012.06.003.

551 Castalanelli MA, Severtson DL, Brumley CJ, Szito A, Foottit RG, Grimm M, Munyard K, Groth

552

553

554

555

556

557

558

559

560

561

562

563

564

565

566

567

DM. 2010. A rapid non-destructive DNA extraction method for insects and other arthropods. Journal of Asia-Pacific Entomology 13:243-248.

DOI:10.1016/j.aspen.2010.04.003.

Clarke LJ, Soubrier J, Weyrich LS, Cooper A. 2014. Environmental metabarcodes for insects: In silicoPCR reveals potential for taxonomic bias. Molecular Ecology Resources 14:11601170. DOI:10.1111/1755-0998.12265.

Cornils A. 2015. Non-destructive DNA extraction for small pelagic copepods to perform integrative taxonomy. Journal of Plankton Research 37:6-10. DOI:10.1093/plankt/fbu105.

Creer S, Fonseca VG, Porazinska DL, Giblin-Davis RM, Sung W, Power DM, Packer M, Carvalho GR, Blaxter ML, Lambshead PJD, Thomas WK. 2010. Ultrasequencing of the meiofaunal biosphere: Practice, pitfalls and promises. Molecular Ecology 19:4-20. DOI:10.1111/j.1365-294X.2009.04473.x.

Cristescu ME. 2014. From barcoding single individuals to metabarcoding biological communities: towards an integrative approach to the study of global biodiversity. Trends in Ecology and Evolution 29:566-571. DOI:10.1016/j.tree.2014.08.001. 
568 Dowle E, Pochon X, Banks J, Shearer K, Wood SA. (2016) Targeted gene enrichment and high 569 throughput sequencing for environmental biomonitoring: A case study using freshwater 570 macroinvertebrates. Molecular Ecology Resources 16:1240-1254. DOI: 10.1111/1755$571 \quad 0998.12488$.

572 Edgar RC, Haas BJ, Clemente JC, Quince C, Knight R. 2011. UCHIME improves sensitivity and 573 speed of chimera detection. Bioinformatics 27:2194-2200.

574 DOI:10.1093/bioinformatics/btr381.

575 Elbrecht V, Leese F. 2015. Can DNA-Based ecosystem assessments quantify species abundance?

576 Testing primer bias and biomass--sequence relationships with an innovative metabarcoding protocol. PLoS ONE 10:e0130324. DOI:10.1371/journal.pone.0130324.

578 Elbrecht V, Leese F. 2017. Validation and development of COI metabarcoding primers for 579 580 freshwater macroinvertebrate bioassessment. Frontiers in Environmental Science 5.

581 Elbrecht V, Peinert B, Leese F. 2017. Sorting things out: Assessing effects of unequal specimen 582 biomass on DNA metabarcoding. Ecology and Evolution 7:6918-6926.

584 Elbrecht V, Vamos EE, Meissner K, Aroviita J, Leese F. 2017. Assessing strengths and 585 weaknesses of DNA metabarcoding-based macroinvertebrate identification for routine 586 587 stream monitoring. Methods in Ecology and Evolution 8: 1265-1275. DOI:10.1111/2041-

588 Folmer O, Black M, Hoeh W, Lutz R, Vrijenhoek R. 1994. DNA primers for amplification of 589 mitochondrial cytochrome c oxidase subunit I from diverse metazoan invertebrates. $590 \quad$ Molecular Marine Biology and Biotechnology 3:294-299. 
591 Gibson J, Shokralla S, Porter TM, King I, van Konynenburg S, Janzen DH, Hallwachs W,

592

593

594

595

596

597

598

599

600

601

602

603

604

605

606

607

608

609

610

611 Hajibabaei M. 2014. Simultaneous assessment of the macrobiome and microbiome in a bulk sample of tropical arthropods through DNA metasystematics. Proceedings of the National Academy of Sciences 111:8007-8012. DOI:10.1073/pnas.1406468111.

Gibson JF, Shokralla S, Curry C, Baird DJ, Monk WA, King I, Hajibabaei M. 2015. Large-scale biomonitoring of remote and threatened ecosystems via high-throughput sequencing. PLoS ONE 10:e0138432. DOI:10.1371/journal.pone.0138432.

Haase P, Lohse S, Pauls S, Schindehuette K, Sundermann A, Rolauffs P, Hering D. 2004. Assessing streams in Germany with benthic invertebrates: Development of a practical standardised protocol for macroinvertebrate sampling and sorting. Limnologica 34:349365. DOI:10.1016/S0075-9511(04)80005-7.

Hajibabaei M, Shokralla S, Zhou X, Singer GAC, Baird DJ. 2011. Environmental Barcoding: A next-generation sequencing approach for biomonitoring applications using river benthos. PLoS ONE 6:e17497. DOI:10.1371/journal.pone.0017497.

Hajibabaei M, Spall J, Shokralla S, van Konynenburg S. 2012. Assessing biodiversity of a freshwater benthic macroinvertebrate community through non-destructive environmental barcoding of DNA from preservative ethanol. BMC Ecology 12:28. DOI:10.1186/1472$6785-12-28$.

Hawking JH. 2000. A preliminary guide to keys and zoological information to identify invertebrates form Australian freshwaters. Identification Guide No 2 (2nd Edition), Cooperative Research Centre for Freshwater Ecology: Albury, Australia.. 
612 Hebert PD, Zakharov EV, Prosser SW, Sones JE, McKeown JT, Mantle B, La Salle J. 2013. A

613 DNA 'Barcode Blitz': Rapid digitization and sequencing of a natural history collection.

$614 \quad$ PLoS ONE 8:e68535. DOI:10.1371/journal.pone.0068535.

615 Hebert PDN, Cywinska A, Ball SL, deWaard JR. 2003. Biological identification through DNA

616 barcodes. Proceedings of the Royal Society of London Series B: Biological Sciences

617 270:313-321. DOI:10.1098/rspb.2002.2218.

618 Hebert PDN, Ratnasingham S, Zakharov EV, Telfer AC, Levesque-Beaudin V, Milton MA,

619 Pedersen S, Jannetta P, deWaard JR. 2016. Counting animal species with DNA barcodes:

620 Canadian insects. Philosophical Transactions of the Royal Society B: Biological Sciences

621 371. DOI:10.1098/rstb.2015.0333.

622 Hendrich L, Morinière J, Haszprunar G, Hebert PDN, Hausmann A, Köhler F, Balke M. 2015. A

623 comprehensive DNA barcode database for Central European beetles with a focus on

624 Germany: Adding more than 3500 identified species to BOLD. Molecular Ecology

$625 \quad$ Resources 15:795-818. DOI:10.1111/1755-0998.12354.

626 Kearse M, Moir R, Wilson A, Stones-Havas S, Cheung M, Sturrock S, Buxton S, Cooper A,

627 Markowitz S, Duran C, Thierer T, Ashton B, Meintjes P, Drummond A. 2012. Geneious

628 Basic: An integrated and extendable desktop software platform for the organization and

629 analysis of sequence data. Bioinformatics 28:1647-1649.

630

DOI:10.1093/bioinformatics/bts199.

631 Kranzfelder P, Ekrem T, Stur E. 2017. DNA Barcoding for Species Identification of Insect

632 Skins: A test on Chironomidae (Diptera) pupal exuviae. Journal of Insect Science

633 17:111-111. DOI:10.1093/jisesa/iex075. 
634 Krosch MN, and Cranston PS. 2012. Non-destructive DNA extraction from Chironomidae,

635 including of fragile pupal exuviae, extends analysable collections and enhances

636 vouchering. Chironomus Newsletter on Chironomidae Research 25:22-27.

637 DOI:10.5324/cjcr.v0i25.1532

638

639

640

641

642

643

644

645

646

647

648

649

650

651

652

653

654

655

656

Lanzén A, Lekang K, Jonassen I, Thompson EM, Troedsson C. 2016. High-throughput metabarcoding of eukaryotic diversity for environmental monitoring of offshore oildrilling activities. Molecular Ecology 25:4392-4406. DOI:10.1111/mec.13761.

Lee MSY. 2004. The molecularisation of taxonomy. Invertebrate Systematics 18:1-6. DOI:10.1071/Is03021.

Leray M, Yang J, Meyer C, Mills S, Agudelo N, Ranwez V, Boehm J, Machida R. 2013. A new versatile primer set targeting a short fragment of the mitochondrial COI region for metabarcoding metazoan diversity: Application for characterizing coral reef fish gut contents. Frontiers in Zoology 10:34.

Magoc T, Salzberg SL. 2011. FLASH: Fast length adjustment of short reads to improve genome assemblies. Bioinformatics 27:2957-2963. DOI:10.1093/bioinformatics/btr507.

Moritz C, Cicero C. 2004. DNA barcoding: Promise and pitfalls. PLoS Biology 2:1529-1531. DOI:10.1371/journal.pbio.0020354.

Pawlowski J, Esling P, Lejzerowicz F, Cedhagen T, Wilding TA. 2014. Environmental monitoring through protist next-generation sequencing metabarcoding: Assessing the impact of fish farming on benthic foraminifera communities. Molecular Ecology Resources 14:1129-1140. DOI:10.1111/1755-0998.12261.

Porco D, Rougerie R, Deharveng L, Hebert P. 2010. Coupling non-destructive DNA extraction and voucher retrieval for small soft-bodied Arthropods in a high-throughput context: The 
657

658

659

660

661

662

663

664

665

666

667

668

669

670

671

672

673

674

675

676

677

678

679

example of Collembola. Molecular Ecology Resources 10:942-945. DOI:10.1111/j.17550998.2010.2839.x.

Rosenberg DM, Resh VH. 1993. Freshwater biomonitoring and benthic macroinvertebrates: Chapman \& Hall.

Rowley DL, Coddington JA, Gates MW, Norrbom AL, Ochoa RA, Vandenberg NJ, Greenstone MH. 2007. Vouchering DNA-barcoded specimens: test of a nondestructive extraction protocol for terrestrial arthropods. Molecular Ecology Notes 7:915-924. DOI:10.1111/j.1471-8286.2007.01905.x.

Schafer RB, Kefford B, Metzeling L, Liess M, Burgert S, Marchant R, Pettigrove V, Goonan P, Nugegoda D. 2011. A trait database of stream invertebrates for the ecological risk assessment of single and combined effects of salinity and pesticides in South-East Australia. Science of the Total Environment 409:2055-2063.

DOI:10.1016/j.scitotenv.2011.01.053.

Stein ED, Martinez MC, Stiles S, Miller PE, Zakharov EV. 2014. Is DNA barcoding actually cheaper and faster than traditional morphological methods: Results from a survey of freshwater bioassessment efforts in the United States? PLoS ONE 9:e95525.

DOI:10.1371/journal.pone.0095525.

Sweeney BW, Battle JM, Jackson JK, Dapkey T. 2011. Can DNA barcodes of stream macroinvertebrates improve descriptions of community structure and water quality? Journal of the North American Benthological Society 30:195-216. DOI:10.1899/10016.1 .

Wong WH, Tay YC, Puniamoorthy J, Balke M, Cranston PS, Meier R. 2014. 'Direct PCR' optimization yields a rapid, cost-effective, nondestructive and efficient method for 
680 obtaining DNA barcodes without DNA extraction. Molecular Ecology Resources

681 14:1271-1280. DOI:10.1111/1755-0998.12275.

682 Yu DW, Ji YQ, Emerson BC, Wang XY, Ye CX, Yang CY, Ding ZL. 2012. Biodiversity soup:

683 Metabarcoding of arthropods for rapid biodiversity assessment and biomonitoring.

$684 \quad$ Methods in Ecology and Evolution 3:613-623. DOI:10.1111/j.2041-210X.2012.00198.x.

685 Zhou X, Li Y, Liu S, Yang Q, Su X, Zhou L, Tang M, Fu R, Li J, Huang Q. 2013. Ultra-deep

686 sequencing enables high-fidelity recovery of biodiversity for bulk arthropod samples

687 without PCR amplification. GigaScience 2:4. DOI:10.1186/2047-217x-2-4.

688 Zimmermann J, Abarca N, Enke N, Skibbe O, Kusber WH, Jahn R. 2014. Taxonomic reference

689 libraries for environmental barcoding: A best practice example from diatom research.

$690 \quad$ PLOS ONE 9:e108793. DOI:10.1371/journal.pone.0108793. 


\section{Table $\mathbf{1}$ (on next page)}

Outline for the experimental workflow for testing non-destructive DNA extraction 
1

\begin{tabular}{|c|c|c|}
\hline 2 Component & Questions & Answers \\
\hline \multirow[t]{3}{*}{$\begin{array}{l}\text { 1. Non-destructive DNA } \\
\text { extraction of single } \\
\text { individuals }\end{array}$} & $\begin{array}{l}\text { Can non-destructive DNA } \\
\text { extraction be used to obtain DNA } \\
\text { from macroinvertebrates? }\end{array}$ & $\begin{array}{l}\text { Yes, but not from taxa with little } \\
\text { sclerotization, such as the } \\
\text { Oligochaeta and Hirudinea. }\end{array}$ \\
\hline & $\begin{array}{l}\text { What is a suitable incubation time } \\
\text { for immersion in extraction buffer } \\
\text { that does not destroy morphological } \\
\text { traits but yields DNA? }\end{array}$ & $\begin{array}{l}\text { An hour works best for most taxa, } \\
\text { but for Amphipoda less time would } \\
\text { be needed to avoid damage to } \\
\text { taxonomic characters. }\end{array}$ \\
\hline & $\begin{array}{l}\text { Can DNA be extracted from a } \\
\text { specimen used for non-destructive } \\
\text { DNA extraction? }\end{array}$ & $\begin{array}{l}\text { Yes, for most taxa this is possible. It } \\
\text { can be difficult for small taxa like } \\
\text { Acarina and some Diptera }\end{array}$ \\
\hline \multirow[t]{2}{*}{$\begin{array}{l}\text { 2. Comparison of bulk non- } \\
\text { destructive extraction to } \\
\text { tissue-based DNA extraction } \\
\text { for metabarcoding samples of } \\
\text { known composition - } \\
\text { multiple individuals }\end{array}$} & $\begin{array}{l}\text { How does bulk non-destructive } \\
\text { (ND) extraction compares to total } \\
\text { homogenization (H) and tissue } \\
\text { dissection (D) based extractions } \\
\text { when detecting taxa with } \\
\text { metabarcoding? }\end{array}$ & $\begin{array}{l}\text { Detection of taxa was similar across } \\
\text { all three extraction methods with } \\
>84 \% \text { of taxa detected. However, } \\
\text { some more sclerotized taxa } \\
\text { (Coleoptera) were often missed by } \\
\text { the ND method compared to other } \\
\text { methods. }\end{array}$ \\
\hline & $\begin{array}{l}\text { Can specimens from bulk ND } \\
\text { extractions be used for DNA } \\
\text { barcoding and taxonomic } \\
\text { identification? }\end{array}$ & $\begin{array}{l}\text { Yes, unlike individual ND } \\
\text { extraction, specimens subject to } \\
\text { bulk ND were largely unaltered and } \\
\text { were easily used for DNA } \\
\text { barcoding and taxonomic } \\
\text { identification }\end{array}$ \\
\hline \multirow{2}{*}{$\begin{array}{l}\text { 3. Non-destructive DNA } \\
\text { extraction of rapid } \\
\text { bioassessment samples stored } \\
\text { for morphological } \\
\text { identification - multiple } \\
\text { individuals }\end{array}$} & $\begin{array}{l}\text { Can taxa be detected in field } \\
\text { samples when ND extraction is } \\
\text { used? }\end{array}$ & $\begin{array}{l}\text { Yes, most taxa were detected using } \\
\text { ND extraction protocol except } \\
\text { Hydrobiidae snail and some small } \\
\text { taxa. }\end{array}$ \\
\hline & $\begin{array}{l}\text { Do storage conditions }(100 \% \\
\text { ethanol with refrigeration) and sub- } \\
\text { optimally ( } 70 \% \text { ethanol at room } \\
\text { temperature) affect taxa detection } \\
\text { success when using non-destructive } \\
\text { DNA extraction? }\end{array}$ & $\begin{array}{l}\text { There were no obvious difference in } \\
\text { the number of taxa detected } \\
\text { between samples stored under } \\
\text { different conditions. }\end{array}$ \\
\hline
\end{tabular}




\section{Table 2 (on next page)}

Results of experiment 1a examining the effect of incubation time in the T1 buffer with proteinase $\mathrm{K}$ (from the Nucleospin DNA extraction kit) on non-destructive total genomic extractions of species from nine invertebrate groups

The success of non-destructive (ND) extraction (Extraction 1) for standard DNA barcoding PCR is indicated by the ' + ' symbol ('-' for no PCR product), while the success of the second Chelex extraction (Extraction 2) on the same material is indicated the adjacent column. GenBank accession numbers for sequenced specimens are given in parenthesis. 


\begin{tabular}{|c|c|c|c|c|c|c|c|c|c|}
\hline \multirow[b]{3}{*}{ Order/Subclass } & \multirow[b]{3}{*}{ Species (Family) } & \multirow[b]{3}{*}{ Sclerotization } & \multirow[b]{3}{*}{$\begin{array}{l}\text { Life } \\
\text { stage }\end{array}$} & \multicolumn{6}{|c|}{ Incubation time for Extraction 1} \\
\hline & & & & & \multicolumn{2}{|l|}{$1 \mathrm{hr}$} & \multicolumn{2}{|l|}{$3 \mathrm{hr}$} \\
\hline & & & & $\begin{array}{l}\text { Extraction } 1 \\
\left(1^{\text {st }} \mathrm{ND}\right)\end{array}$ & $\begin{array}{l}\text { Extraction } 2 \\
\left(2^{\text {nd }} \text { Chelex }\right)\end{array}$ & $\begin{array}{l}\text { Extraction } 1 \\
\left(1^{\text {st }} \mathrm{ND}\right)\end{array}$ & $\begin{array}{l}\text { Extraction } 2 \\
\left(2^{\text {nd }} \text { Chelex }\right)\end{array}$ & $\begin{array}{l}\text { Extraction } \\
1 \\
\left(1^{\text {st }} \mathrm{ND}\right)\end{array}$ & $\begin{array}{l}\text { Extraction } \\
2 \\
\left(2^{\text {nd }}\right. \\
\text { Chelex })\end{array}$ \\
\hline Oligochaeta & $\begin{array}{l}\text { Lumbriculus } \\
\text { variegatus } \\
\text { (Lumbriculidae) }\end{array}$ & Soft bodied & Adult & $\begin{array}{l}+ \\
\text { (MG976202) }\end{array}$ & - & + & - & & \\
\hline Gastropoda & $\begin{array}{l}\text { Physa acuta } \\
\text { (Physidae) }\end{array}$ & $\begin{array}{l}\text { soft } \\
\text { bodied/shell }\end{array}$ & Adult & $\begin{array}{l}+ \\
(\mathrm{MG} 976201)\end{array}$ & $\begin{array}{l}+ \\
\text { (MG976114) }\end{array}$ & + & + & + & - \\
\hline Amphipoda & $\begin{array}{l}\text { Austrochiltonia } \\
\text { subtenuis } \\
\text { (Chiltoniidae) }\end{array}$ & $\begin{array}{l}\text { light } \\
\text { sclerotized }\end{array}$ & Adult & $\begin{array}{l}+ \\
(\mathrm{MG} 976104)\end{array}$ & + & + & + & & \\
\hline Diptera & $\begin{array}{l}\text { Procladius } \\
\text { villosimanus } \\
\text { (Chironomidae) }\end{array}$ & $\begin{array}{l}\text { sclerotized } \\
\text { head }\end{array}$ & Larvae & & & $\begin{array}{l}+ \\
(\mathrm{MG} 976143)\end{array}$ & $\begin{array}{l}+ \\
(\mathrm{MG} 976144)\end{array}$ & + & + \\
\hline Trichoptera & $\begin{array}{l}\text { Hellyethira simplex } \\
\text { (Hydroptilidae) }\end{array}$ & $\begin{array}{l}\text { sclerotized } \\
\text { head and } \\
\text { thorax }\end{array}$ & Larvae & $\begin{array}{l}+ \\
(\mathrm{MG} 976170)\end{array}$ & $\begin{array}{l}+ \\
(\mathrm{MG} 976171)\end{array}$ & $+(+)$ & & & \\
\hline Ephemeroptera & $\begin{array}{l}\text { Offadens sp. } \\
\text { (Baetidae) }\end{array}$ & sclerotized & Nymph & $\begin{array}{l}+ \\
\text { (MG976108) }\end{array}$ & $\begin{array}{l}+ \\
\text { (MG976109) }\end{array}$ & $+(+)$ & & & \\
\hline Plecoptera & $\begin{array}{l}\text { Dinotoperla thwaites } \\
\text { (Gripopterygidae) }\end{array}$ & sclerotized & Nymph & $\begin{array}{l}+ \\
(\mathrm{MG} 976167)\end{array}$ & $\begin{array}{l}+ \\
\text { (MG976167) }\end{array}$ & $+(+)$ & & & \\
\hline Hemiptera & $\begin{array}{l}\text { Micronecta sp. } \\
\text { (Corixidae) }\end{array}$ & sclerotized & Adult & $\begin{array}{l}+ \\
(\mathrm{MG} 976178)\end{array}$ & $\begin{array}{l}+ \\
\text { (MG976178) }\end{array}$ & $+(+)$ & & & \\
\hline Coleoptera & $\begin{array}{l}\text { Necterosoma sp. } \\
\text { (Dytiscidae) }\end{array}$ & $\begin{array}{l}\text { heavily } \\
\text { sclerotized }\end{array}$ & Adult & - & + & $\begin{array}{l}+ \\
(\mathrm{MH} 000193)\end{array}$ & $\begin{array}{l}+* \\
(\mathrm{MH} 000194)\end{array}$ & + & $+*$ \\
\hline
\end{tabular}

* Extraction 2 using crushed legs failed, but $2 \mathrm{hr}$ incubation of whole animal in Chelex (with proteinase K) was successful. 


\section{Table 3(on next page)}

Results of experiment $1 \mathrm{~b}$ examining non-destructive DNA extraction trial on individuals from multiple macroinvertebrate groups.

A breakdown of the species in each family can be found in Table S1. 
1

\begin{tabular}{|c|c|c|c|c|c|c|c|c|}
\hline \multirow{2}{*}{$\begin{array}{c}\text { Higher } \\
\text { Taxonomic rank }\end{array}$} & \multirow[b]{2}{*}{ Sclerotization } & \multirow[b]{2}{*}{ Families } & \multicolumn{2}{|c|}{ Material for extraction } & \multirow[b]{2}{*}{$\begin{array}{c}\text { Individuals } \\
\text { tested }\end{array}$} & \multicolumn{3}{|c|}{ Number of individuals with successful extractions } \\
\hline & & & Extraction 1 & Extraction 2 & & $\begin{array}{c}\text { Extraction } 1 \\
\left(1^{\text {st }} \mathrm{ND}\right)\end{array}$ & $\begin{array}{l}\text { Extraction } 2 \\
\left(2^{\text {nd }} \text { Chelex }\right) \\
\end{array}$ & $\begin{array}{c}\text { Both } \\
\text { extractions }\end{array}$ \\
\hline Acarina & moderate & $2 *$ & whole animal & whole animal & 6 & 4 & 1 & 1 \\
\hline Oligochaeta & soft bodied & $3^{*}$ & whole animal & no material & 5 & 5 & 0 & 0 \\
\hline Hirudinea & soft bodied & 1 & whole animal & no material & 1 & 1 & 0 & 0 \\
\hline Bivalvia & $\begin{array}{l}\text { soft bodied/ } \\
\text { shell }\end{array}$ & 1 & whole animal & no material & 3 & 2 & 0 & 0 \\
\hline Gastropoda & $\begin{array}{l}\text { soft bodied/ } \\
\text { shell }\end{array}$ & 2 & whole animal & Whole animal & 5 & 5 & 4 & 4 \\
\hline Diptera & $\begin{array}{l}\text { Little - } \\
\text { moderate }\end{array}$ & 6 & whole animal & tissue sample & 12 & 11 & 5 & 5 \\
\hline Trichoptera & moderate & 5 & whole animal & whole animal/leg & 8 & 8 & 8 & 8 \\
\hline Ephemeroptera & moderate & 2 & whole animal & leg & 4 & 4 & 4 & 4 \\
\hline Plecoptera & moderate & 2 & whole animal & leg & 4 & 4 & 4 & 4 \\
\hline Hemiptera & $\begin{array}{l}\text { moderate - } \\
\text { heavy }\end{array}$ & 3 & whole animal & leg & 4 & 4 & 4 & 4 \\
\hline Coleoptera & $\begin{array}{l}\text { moderate - } \\
\text { heavy }\end{array}$ & 5 & whole animal & leg & 8 & 8 & 8 & 8 \\
\hline Amphipoda & moderate & 2 & whole animal & leg & 4 & 4 & 4 & 4 \\
\hline Megaloptera & moderate & 1 & whole animal & leg & 1 & 1 & 1 & 1 \\
\hline Decapoda & $\begin{array}{l}\text { moderate - } \\
\text { heavy }\end{array}$ & 2 & whole animal & leg & 2 & 2 & 2 & 2 \\
\hline Odonata & moderate & 1 & whole animal & leg & 1 & 1 & 1 & 1 \\
\hline
\end{tabular}

*All families in these orders were not identified. Lowest possible identifications are given. 


\section{Table 4(on next page)}

Sample preparation and comparison of species detection using metabarcoding based on three DNA extraction methods.

Extraction methods are based on non-destructive (ND), homogenization (H) and dissection (D) in samples of known taxonomic composition containing 80,100 or 120 individuals. 
1

\begin{tabular}{lcccc}
\hline & $\begin{array}{c}\text { Extraction } \\
\text { method }\end{array}$ & $\begin{array}{c}\text { Sample A } \\
80 \text { individuals }\end{array}$ & $\begin{array}{c}\text { Sample B } \\
100 \text { individuals }\end{array}$ & $\begin{array}{c}\text { Sample C } \\
\text { 120 individuals } \\
\text { technical replicate) }\end{array}$ \\
\hline Time taken to prepare sample for DNA & ND & 10 & 15 & 10 \\
extraction (min) & $\mathrm{H}$ & 7 & 10 & 8 \\
& $\mathrm{D}$ & 21 & 20 & 27 \\
\hline Number of DNA extraction tubes required & $\mathrm{ND}$ & 2 & 2 & 2 \\
& $\mathrm{H}$ & 3 & 3 & 3 \\
\hline Number of species detected with HTS & $\mathrm{D}$ & 1 & 1 & $40(40)$ \\
& $\mathrm{ND}$ & 46 & 33 & $37(38)$ \\
& $\mathrm{H}$ & 38 & 45 & $41(42)$ \\
\hline \% of expected species or genera detected & $\mathrm{D}$ & 47 & 41 & $98(98)$ \\
with metabarcoding compared to samples & $\mathrm{ND}$ & 93 & 89 & $98(100)$ \\
of known taxonomic composition & $\mathrm{H}$ & 88 & 100 & $98(100)$ \\
\hline
\end{tabular}

2 


\section{Table 5 (on next page)}

Amplicon size and number of reads (sequences) obtained for each of the three amplicons used for HTS.

Samples include three sets of constructed samples containing 3 replicates extracted using non-destructive (ND), complete homogenization (H) and dissection (D) based DNA extraction protocols, and six field-collected macroinvertebrate samples from three sites along Merri Creek (Melbourne, Australia) extracted using a non-destructive extraction protocol. 
1

\begin{tabular}{|c|c|c|c|c|c|c|}
\hline \multirow{2}{*}{$\begin{array}{l}\text { Sample (number of } \\
\text { individuals) }\end{array}$} & \multirow{2}{*}{$\begin{array}{l}\text { Extraction } \\
\text { method }\end{array}$} & \multirow{2}{*}{$\begin{array}{r}\begin{array}{r}\text { LCOI/MLepR2 } \\
\text { amplicon }\end{array} \\
280 \mathrm{bp} \\
\end{array}$} & \multirow{2}{*}{$\begin{array}{r}\begin{array}{r}\text { B/COIBrev } \\
\text { amplicon }\end{array} \\
293 \mathrm{bp} \\
\end{array}$} & \multicolumn{2}{|l|}{$\begin{array}{r}\text { mtCOIintF/HCOI } \\
\text { amplicon } \\
\end{array}$} & \multirow{2}{*}{$\begin{array}{c}\text { Overall species } \\
\text { detection } \\
\text { success }(\%)\end{array}$} \\
\hline & & & & $313 b p$ & Total & \\
\hline \multicolumn{7}{|c|}{ Samples of known composition: } \\
\hline \multirow{3}{*}{$\begin{array}{l}\text { Sample A } \\
(80)\end{array}$} & ND & 48288 & 56031 & 44645 & 148964 & 92 \\
\hline & $\mathrm{H}$ & 117667 & 116313 & 61850 & 295830 & 84 \\
\hline & $\mathrm{D}$ & 79356 & 86299 & 38716 & 204371 & 97 \\
\hline \multirow{3}{*}{$\begin{array}{l}\text { Sample B } \\
(100)\end{array}$} & ND & 67448 & 75433 & 19463 & 162344 & 89 \\
\hline & $\mathrm{H}$ & 44783 & 49313 & 14826 & 108922 & 100 \\
\hline & $\mathrm{D}$ & 111207 & 124103 & 68281 & 303591 & 100 \\
\hline \multirow{3}{*}{$\begin{array}{l}\text { Sample C } \\
(120)\end{array}$} & ND & 76164 & 54706 & 32963 & 163833 & 95 \\
\hline & $\mathrm{H}$ & 39418 & 65326 & 24561 & 129305 & 95 \\
\hline & $\mathrm{D}$ & 79524 & 109656 & 26218 & 215398 & 95 \\
\hline \multirow{3}{*}{$\begin{array}{l}\text { Sample C } \\
(120) \\
\text { technical replicate }\end{array}$} & ND & 70875 & 65871 & 20231 & 156977 & 95 \\
\hline & $\mathrm{H}$ & 86622 & 134934 & 24233 & 245789 & 100 \\
\hline & $\mathrm{D}$ & 50590 & 93821 & 26826 & 171237 & 100 \\
\hline \multicolumn{7}{|c|}{ Field collected samples: } \\
\hline MRD 2016 & ND & 75891 & 44593 & 69640 & 190124 & 88 \\
\hline MRD 2014 & ND & 69445 & 43188 & 57083 & 169716 & 73 \\
\hline MOH 2016 & ND & 47943 & 41761 & 57124 & 146828 & 83 \\
\hline MOH 2014 & ND & 67644 & 49726 & 39482 & 156852 & 80 \\
\hline MCL 2016 & ND & 81108 & 15177 & 60074 & 156359 & 73 \\
\hline MCL 2014 & ND & 727 & 687 & 164 & 1578 & 55 (low reads) \\
\hline
\end{tabular}




\section{Figure 1 (on next page)}

Diagram of the workflow for testing the success of non-destructive DNA extraction.

(A) Individual non-destructive DNA extraction (Extraction 1) followed by a Chelex extraction (Extraction 2) performed on single specimens from 15 different macroinvertebrate orders (Component 1). (B) Comparison of the detection of taxa via metabarcoding by using three DNA extraction based on non-destructive processing, homogenization of whole small taxa and dissection of all taxa (Component 2). (C) Comparison of the detection of taxa via metabarcoding from 6 field collected samples stored in different ethanol concentration, and temperatures an with varying levels of diversity. Drawings by Melissa Carew. 
(A)

$\left.\begin{array}{c}\text { Component 1: Individual } \\ \text { non-destructive DNA } \\ \text { extraction } \\ \text { Whole specimen } \\ \text { placed in T1 buffer } \\ \text { with proteinase K } \\ \text { for } 1 \mathrm{hr}^{*} \text { then } \\ \text { removed } \\ \text { Specimen removed } \\ \text { and total genomic } \\ \text { DNA extraction } \\ \text { completed } \\ \text { Specimen placed in } \\ 100 \% \text { ethanol for } \\ \text { taxonomic } \\ \text { examination } \\ \text { Chelex extraction } \\ \text { completed using } \\ \text { crushed leg/ tissue } \\ \text { or second } \\ \text { immersion of } \\ \text { specimen }\end{array}\right]$

(B)

\section{Component 2: Comparison of bulk non-destructive DNA to tissue-based} DNA extractions for metabarcoding samples of known composition Specimens
processed whole $(w)$ or dissected (d) (legs/tissue)

Small taxa placed in $100 \%$ ethanol for individual DNA barcoding/ morphological examination

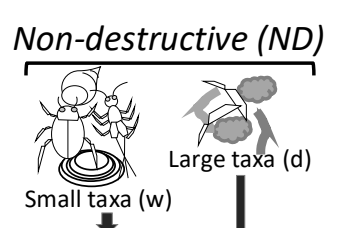

Homogenization $(H)$

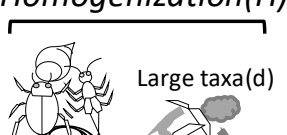

$$
\text { Small taxa (w) }
$$

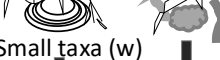

Dissection (D)

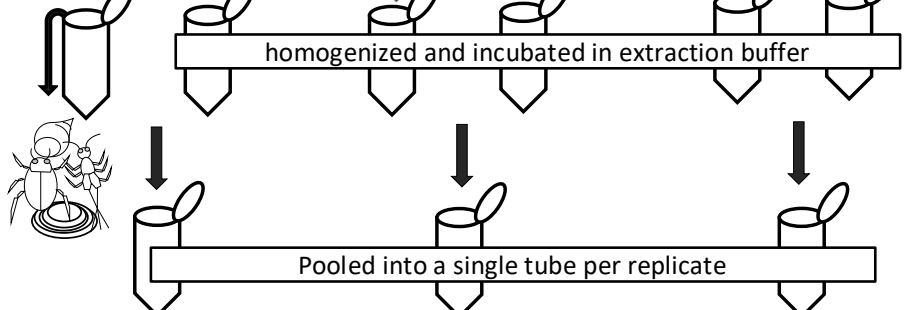

No. of individuals
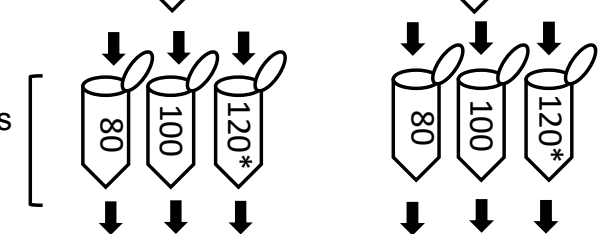

$\downarrow \downarrow$

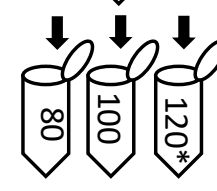

$\downarrow \downarrow$

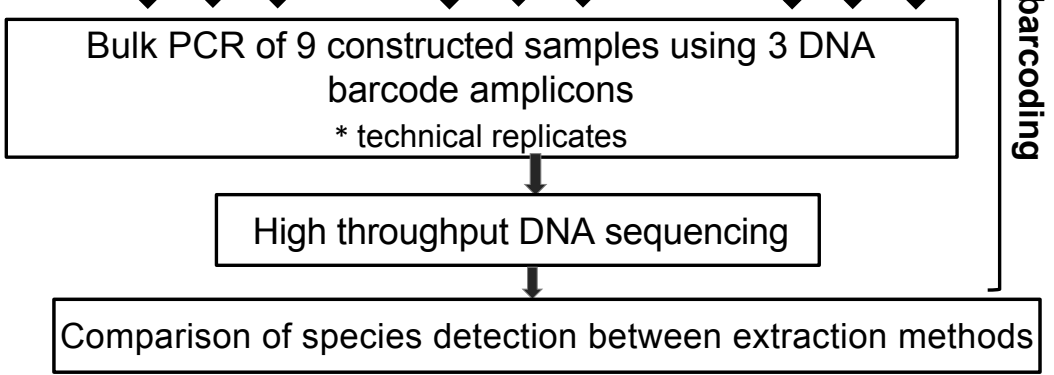

(C)

Component 3: Bulk non-destructive DNA extraction on 6 field samples (varying diversity and storage)

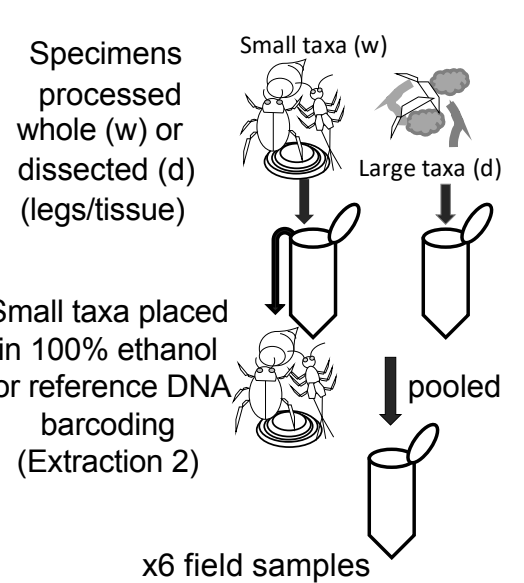

(x3 $100 \%$ ethanol storage at $4^{\circ} \mathrm{C}+\mathrm{x} 3$ $70 \%$ ethanol storage at room temp.)

Bulk PCR using 3 DNA barcode amplicons 1

High throughput DNA sequencing

examination of detection success of species in samples 


\section{Figure 2 (on next page)}

High throughput DNA sequencing of nine constructed samples of known taxonomic composition extracted using non-destructive (ND), complete homogenization $(\mathrm{H})$ and dissection (D) based DNA extraction protocols.

Samples contain 80,100 or 120 individuals. Sample C was run with a technical replicate. The greyscale indicates the number of reads (sequences) returned that match each taxon and ' $n$ ' the number of specimens used from each taxonomic group to compose samples. Species underlined were 'small taxa' extracted using the non-destructive method. Note: the Leptophlebiidae could not be easily distinguished as many specimens were missing legs and were early instars, so detection within samples with the same number of individuals varied. 


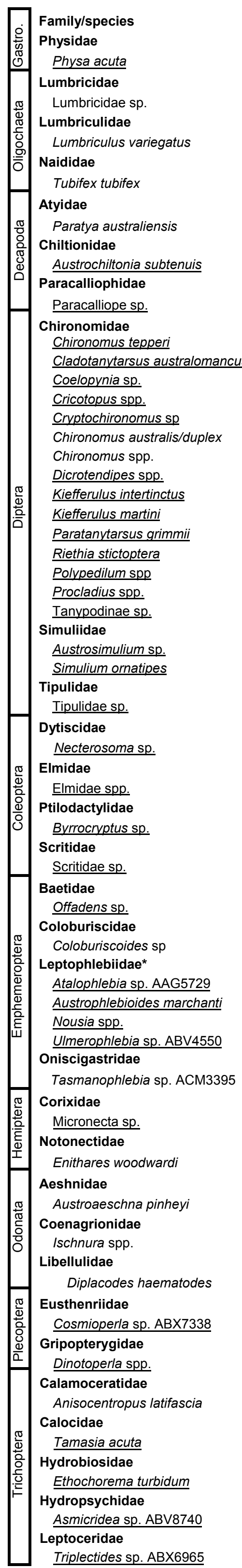

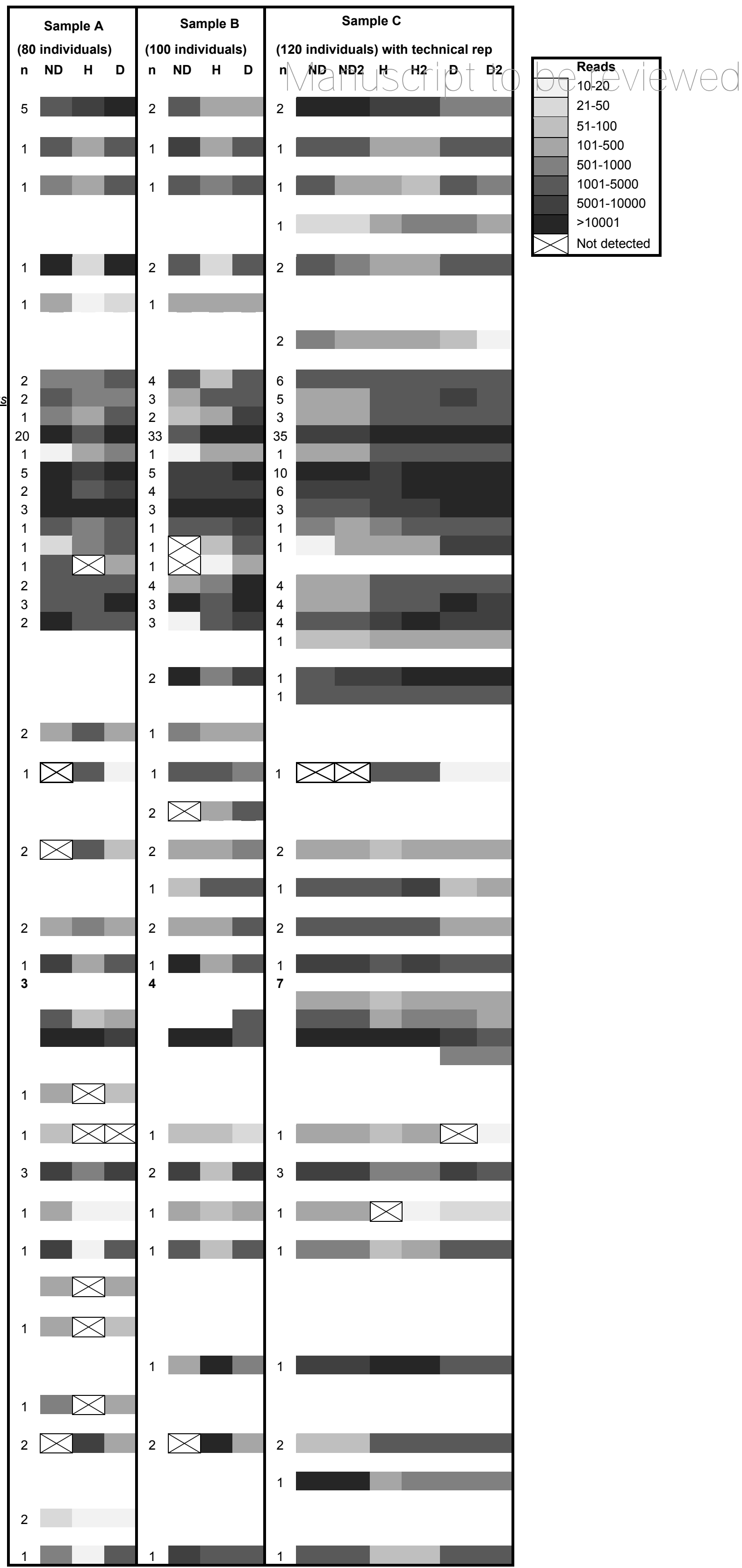




\section{Figure 3 (on next page)}

High-throughput DNA sequencing of six field-collected samples from Merri Creek 20142016.

Sites in Melbourne, Australia include Merri Creek at Coburg Lake, Coburg (MCL); Merri Creek at O'Herns Road, Broadmeadows (MOH) and Merri Creek at Rushwood Drive, Craigieburn (MRD). The greyscale indicates the number of reads (sequences) returned that match each taxon and ' $n$ ' the number of individuals morphologically identified from each family. Species underlined were 'small taxa' extracted using the non-destructive method. Some species with unclear taxonomy are listed by their BOLD BIN (three letters and four numbers) which can be used to find the sequence data and taxonomic information on the taxon on the BOLD version 3 website at www.http://v3.boldsystems.org 


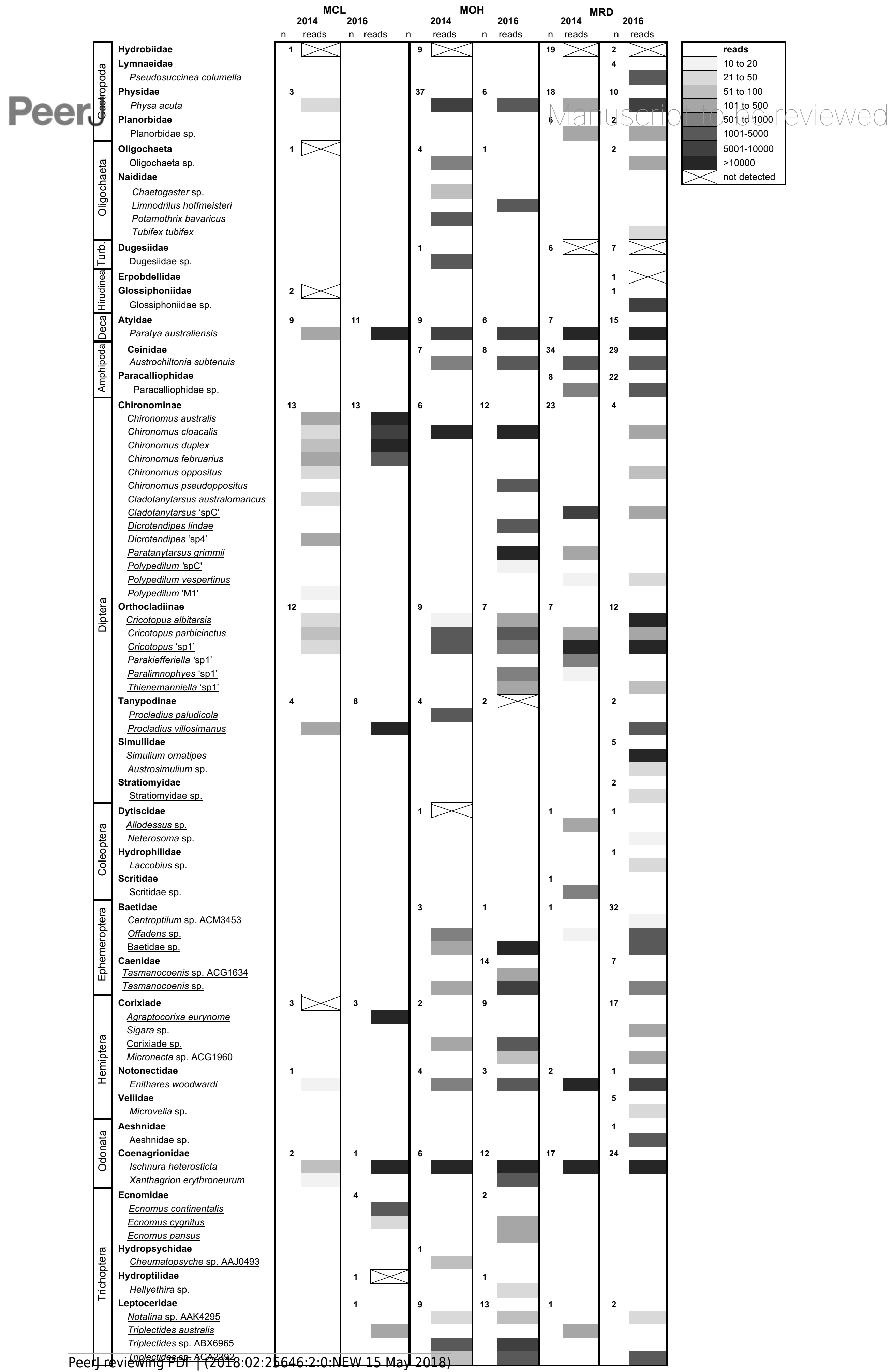

